\title{
The identity of the acid and alkaline phosphatases of human seminal plasma
}

\author{
J. P. Kavanagh and W. G. Bardsley \\ Department of Obstetrics and Gynaecology, University of Manchester, St. Mary's Hospital, \\ Manchester M13 OJH, U.K.
}

\begin{abstract}
Summary. Examination of human seminal plasma showed that there was no $p$ nitrophenylphosphatase activity maximum at alkaline $\mathrm{pH}$ values. A constant ratio of enzyme activities in 8 split ejaculates, identical temperature dependence and copurification through a three-step purification procedure led us to conclude that the alkaline phosphatase in human semen is identical to acid phosphatase.
\end{abstract}

\section{Introduction}

The terms acid and alkaline phosphatase were first proposed by Davies (1934) to distinguish phosphatases with widely different $\mathrm{pH}$ optima. The difference between the two groups of enzymes is also reflected in their substrate specificity. Alkaline phosphatase will hydrolyse $\mathbf{S}$ substituted monoesters of phosphorothioic acid $\left(\mathrm{R}-\mathrm{SPO}_{3} \mathrm{H}_{2}\right)$ and not O-substituted monoesters of phosphorothioic acid $\left(\mathrm{R}-\mathrm{OPO}_{2} \mathrm{H}_{2}\right)$ and the reverse applies to acid phosphatase (Hollander, 1971). Another major distinction lies in the activation by $\mathrm{Mg}^{2+}$ and inhibition by metal chelating agents of alkaline phosphatase and not acid phosphatase (Fernley, 1971).

It has been known for a long time that human seminal plasma is a rich source of acid (prostatic) phosphatase (Kutscher \& Wolbergs, 1935). Gutman \& Gutman (1941) were the first to report an alkaline phosphatase activity (at pH 9.0) in human seminal fluid, although with a very much lower activity than the acid phosphatase. We were interested in this alkaline phosphatase as a possible example of a seminal metaloenzyme and so attempted to identify optimal conditions for its measurement. However, we were unable to demonstrate a $\mathrm{pH}$ optimum in the alkaline region, hence we have considered the possibility that the low phosphatase activity under alkaline conditions is due to acid phosphatase.

\section{Materials and Methods}

Seminal plasma. Human semen was obtained as split ejaculates, collected in two portions, from patients undergoing investigation at the Fertility Clinic, St. Mary's Hospital, Manchester. Each portion of the ejaculate was centrifuged to remove spermatozoa and the seminal plasma was frozen for later analysis. Before use, it was diluted between 10- and 100 -fold with $0.1 \mathrm{M}$ Tris- $\mathrm{HCl}$ buffer, $\mathrm{pH} 7 \cdot 0$.

Phosphatase assays. Disodium p-nitrophenyl phosphate (B.D.H. Ltd, Poole, Dorset) was used as substrate, at a concentration of $1 \mathrm{mM}$. 'Acid' phosphatase (EC 3.1.3.2) was measured at $\mathrm{pH} 5.0$ in $0.1 \mathrm{M}$-sodium acetate buffer and 'alkaline' phosphatase (EC 3.1.3.1) at pH 8.5 in 0.1 $\mathrm{M}$-Tris- $\mathrm{HCl}$ buffer. Diluted seminal plasma $(10 \mu \mathrm{l})$ was added to $1 \mathrm{ml}$ of buffer substrate solution to initiate the reaction, which was followed at $405 \mathrm{~nm}$ in a Cary $118 \mathrm{C}$ recording spectrophotometer at $22^{\circ} \mathrm{C}$. When measuring the activity versus $\mathrm{pH}$ profile, the following buffers were used: $\mathrm{pH} 3 \cdot 5-6 \cdot 2,0.1 \mathrm{M}$-citrate; $\mathrm{pH} \mathrm{6.2-7.4,0.1} \mathrm{M-imidazole-HCl;} \mathrm{pH} 7 \cdot 0-8 \cdot 7$, $0.1 \mathrm{M}$-Tris-HCl; $\mathrm{pH} 8.6-10.5,0.1 \mathrm{~m}$-glycine-NaOH. One international unit of enzyme activity 
is the amount required to convert $1 \mu \mathrm{mol}$ of substrate/min under the stated conditions. This is not simply proportional to the rate of change of absorbance at $405 \mathrm{~nm}$ as below about $\mathrm{pH} 9.0$ the absorbance of the product, $p$-nitrophenol, decreases with decreasing $\mathrm{pH}$. This was taken into account by noting the absorbance of a standard solution of $p$-nitrophenol (B.D.H. Ltd) at the various $\mathrm{pH}$ values used. Hence the activity could be calculated in terms of product produced rather than $\Delta \mathrm{A}_{405}$. If this correction was not performed, there appeared to be more alkaline phosphatase than acid. For example, in Text-fig. 3 the $\Delta \mathbf{A}_{40 \text { s }}$ under alkaline conditions is greater than that under acid conditions although converting to international units shows that the reverse relationship holds (Table 2 ).

Purification of phosphatase. All steps were carried out at $4^{\circ} \mathrm{C}$. Activity measurements under acid and alkaline conditions were performed for all stages. A 9-ml volume of pooled first-portion seminal plasma was diluted to $20 \mathrm{ml}$ with $0.1 \mathrm{M}$-imidazole buffer, $\mathrm{pH} 7 \cdot 0$. Analar $\left(\mathrm{NH}_{4}\right)_{2} \mathrm{SO}_{4}$ was added slowly until $20 \%$ saturation was reached. The precipitate $(0-20 \%$ fraction) was removed by centrifugation at $22000 \mathrm{~g}$ for $40 \mathrm{~min}$ and the supernatant was brought to $40 \%$ saturation with $\left(\mathrm{NH}_{4}\right)_{2} \mathrm{SO}_{4}$. Similarly a $40-60 \%$ fraction was obtained, containing almost $50 \%$ of the total activity. This was resuspended in the minimum volume $(4 \mathrm{ml})$ of $0.1 \mathrm{M}$-imidazole buffer, pH 7.0, and applied to a Sephadex-Sephacryl S-200 column $(2.6 \times 31 \mathrm{~cm})$, preequilibrated with the above buffer and eluted with the same buffer at a rate of $9 \mathrm{ml} / \mathrm{h}$. The most active fractions were pooled and applied to a DEAE-cellulose column $(1.5 \times 30 \mathrm{~cm})$, preequilibrated with $0.05 \mathrm{M}$-Tris- $\mathrm{HCl}$ buffer, $\mathrm{pH} 7.0$, and eluted with $200 \mathrm{ml}$ of the same buffer followed by $200 \mathrm{ml}$ of a salt gradient of $0-0.5 \mathrm{M}-\mathrm{NaCl}$ in the same buffer. The most active fractions were pooled and concentrated by ultracentrifugation.

Protein estimations were by comparison of the absorbance at $280 \mathrm{~nm}$ and $260 \mathrm{~nm}$ (Warburg \& Christian, 1941).

\section{Results}

A preliminary investigation to determine the $\mathrm{pH}$ optimum of seminal alkaline phosphatase showed that the activity continuously decreased with increasing $\mathrm{pH}$ between $\mathrm{pH} 5.7$ and 10.5 and that there was no maximum in the alkaline region (Text-fig. 1).

In order to compare the ratio of 'acid' to 'alkaline' phosphatase in different ejaculates, the mean activities and $95 \%$ confidence limits were calculated, from at least 4 estimations for each of 4 first-portion and 4 second-portion split ejaculates. The range of 'acid' to 'alkaline' activity ratios which has a probability of 0.95 of containing the true ratios for each sample was calculated as $(x-a) /(y+b):(x+a) /(y-b)$; where $x=$ mean 'acid' activity and $a=$ its associated $95 \%$ confidence limits, $y=$ mean 'alkaline' activity and $b=$ its associated $95 \%$ confidence limits. These results, presented in Table 1 , indicate that the ratio of activities in different ejaculates did not significantly differ from one another, despite the wide variation between absolute activity values of different samples.

The temperature dependence of phosphatase activity was investigated by incubating pooled seminal plasma at various temperatures and withdrawing samples at intervals for assay under acid or alkaline conditions. At $36^{\circ} \mathrm{C}$ no detectable loss of activity was observed at pH 5.0 or 8.5 over $30 \mathrm{~min}$. At higher temperatures, activity decreased exponentially with time. First-order rate constants $(k)$ were calculated (by linear regression) as the gradient of semi-logarithmic plots and replotted as $\ln k$ against the reciprocal of the absolute temperature. Similar results were obtained under acid and alkaline conditions (Text-fig. 2).

Throughout the three-step purification procedure, the acid and alkaline activities co-purified. The activities co-eluted from Sephacryl S-200 (Text-fig. 3a) as a major peak and a minor peak (about $2 \%$ of total activity) and from DEAE-cellulose (Text-fig. $3 \mathrm{~b}$ ) as a single peak. Details of the purification and the ratio of acid to alkaline activities are shown in Table 2. 


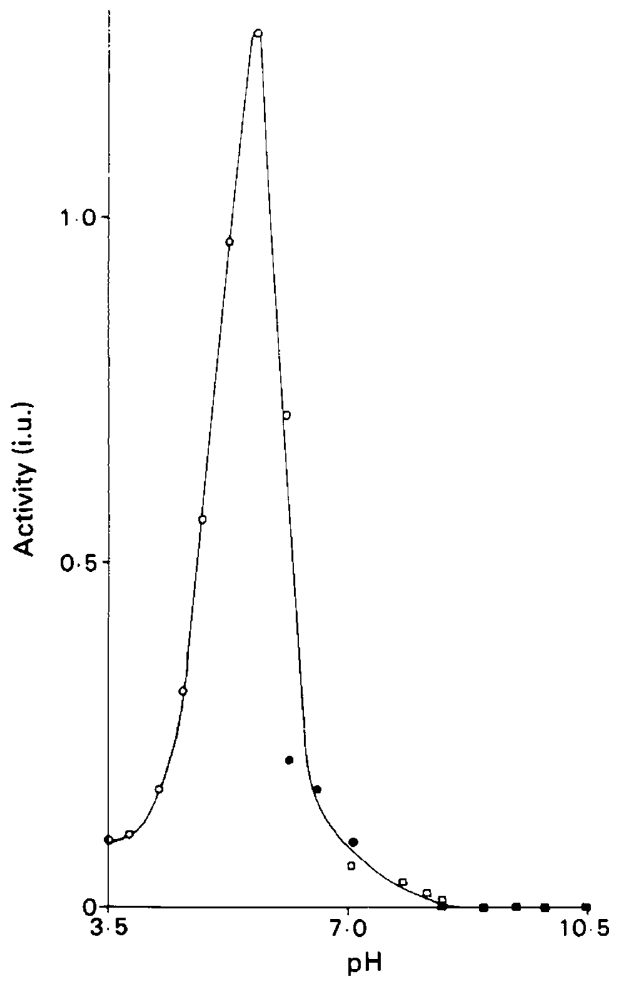

Text-fig. 1. Phosphatase activity in human semen as a function of $\mathrm{pH}: 0.1 \mathrm{M}$-citrate buffer $(\mathrm{O}) ; 0.1 \mathrm{M}$-imidazole-HCl buffer (O); 0.1 M-Tris-HCl buffer ( $\square$ ); $0.1 \mathrm{M}$-glycine-NaOH buffer (正.

Table 1. Acid and alkaline activities (mean with $95 \%$ confidence limits) in different ejaculates of men

\begin{tabular}{|c|c|c|c|c|c|}
\hline \multirow[b]{2}{*}{ Donor } & \multirow[b]{2}{*}{ Sample } & \multicolumn{2}{|c|}{ Activity (i.u./ml) } & \multirow{2}{*}{$\begin{array}{l}\text { Ratio of } \\
\text { acid/alkaline }\end{array}$} & \multirow[b]{2}{*}{$95 \%$ range* } \\
\hline & & Acid & Alkaline & & \\
\hline A & 1 & $195 \pm 26$ & $2.30 \pm 0.22$ & 85 & $67-106$ \\
\hline B & 2 & $488 \pm 103$ & $5.19 \pm 0.17$ & 94 & $65-134$ \\
\hline $\mathrm{C}$ & 3 & $1428 \pm 72$ & $16.01 \pm 2.73$ & 89 & $72-113$ \\
\hline D & 4 & $565 \pm 103$ & $3.55 \pm 3.11$ & 159 & $69-1518$ \\
\hline A & 5 & $108 \pm 26$ & $1.42 \pm 0.16$ & 76 & $52-106$ \\
\hline B & 6 & $57 \pm 15$ & $0.38 \pm 0.11$ & 150 & $86-267$ \\
\hline C & 7 & $241 \pm 93$ & $3.55 \pm 0.11$ & 68 & $40-97$ \\
\hline $\mathrm{E}$ & 8 & $211 \pm 15$ & $3.06 \pm 0.55$ & 69 & $54-90$ \\
\hline
\end{tabular}

Samples 1-4 are first-portion ejaculates, 5-8 are second portion.

* The range of ratios which has a probability of 0.95 of containing the true ratio.

\section{Discussion}

The acceptance of the presence of alkaline phosphatase in human semen is due to the ability to measure phosphatase activity at high $\mathrm{pH}$ values rather than to the demonstration of an enzyme discrete from the acid phosphatase (Gutman \& Gutman, 1941; Wislocki, 1950; Bell \& Lake, 1962; Moon \& Bunge, 1968; Murdoch \& White, 1968; Bostrom, 1971; Kipping, 1971; 
Dondero, Pozza, Mazzulli \& Isidori, 1976; Kock et al., 1976). This belief has probably been strengthened by the knowledge that, in other species, two different enzymes do seem to exist. For example, separate $\mathrm{pH}$ optima at 4.8 to 5.0 and at $\mathrm{pH} 9.4$ have been observed in bull and ram semen (Bouchilloux \& Menager, 1952) and in many species (e.g. bull, boar and rabbit) alkaline phosphatase is present in greater amounts than acid phosphatase (Bell \& Lake, 1962).

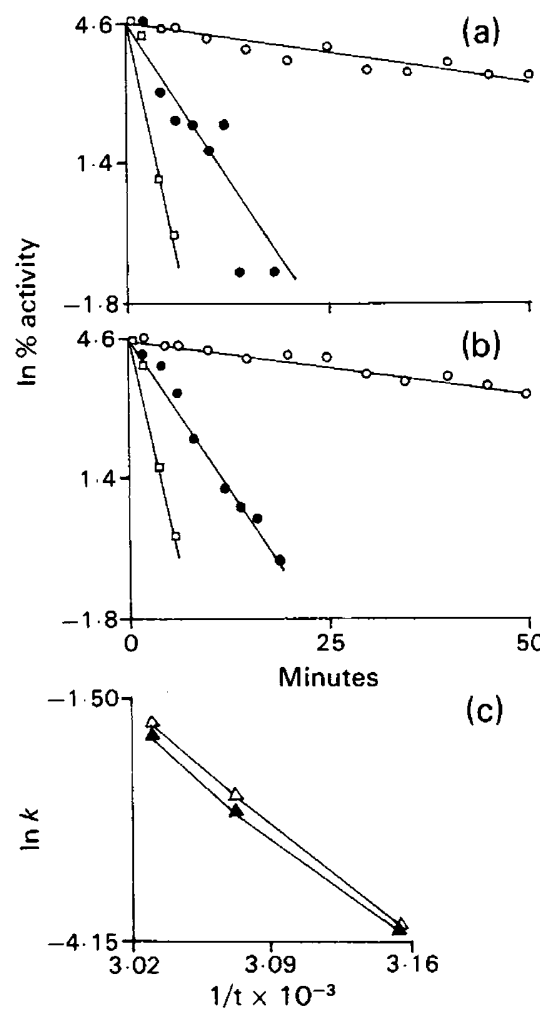

Text-fig. 2. Temperature dependence of phosphatase activities in human semen. Semilogarithmic plots of inactivation are given at $44^{\circ} \mathrm{C}(\mathrm{O}), 52.5^{\circ} \mathrm{C}(\odot)$ and $57^{\circ} \mathrm{C}(\square)$ for (a) acid phosphatase and (b) alkaline phosphatase. (c) Arrhenius plot of inactivation constants for acid phosphatase $(\Delta)$ and alkaline phosphatase $(\triangle)$.

Table 2. Co-purification of acid and alkaline activities from human semen

\begin{tabular}{|c|c|c|c|c|c|c|c|}
\hline \multirow[b]{2}{*}{$\begin{array}{l}\text { Purification } \\
\text { procedure }\end{array}$} & \multirow[b]{2}{*}{$\begin{array}{c}\text { Volume } \\
(\mathrm{ml})\end{array}$} & \multirow[b]{2}{*}{$\begin{array}{l}\text { Protein } \\
(\mathrm{mg})\end{array}$} & \multicolumn{2}{|c|}{ Acid activity } & \multicolumn{2}{|c|}{ Alkaline activity } & \multirow[b]{2}{*}{$\begin{array}{l}\text { Ratio of } \\
\text { acid/alkaline }\end{array}$} \\
\hline & & & $\begin{array}{l}\text { Total } \\
\text { (i.u.) }\end{array}$ & $\begin{array}{l}\text { Sp. act. } \\
\text { (i.u.) }\end{array}$ & $\begin{array}{l}\text { Total } \\
\text { (i.u.) }\end{array}$ & $\begin{array}{l}\text { Sp. act. } \\
\text { (i.u.) }\end{array}$ & \\
\hline Pooled seminal plasma & 9 & 295 & 2773 & 9.4 & 43 & 0.15 & 64.5 \\
\hline $20-100 \%\left(\mathrm{NH}_{4}\right)_{2} \mathrm{SO}_{4}$ & 19.5 & 254 & 2553 & $10 \cdot 1$ & 38 & 0.15 & 67.2 \\
\hline $40-100 \%\left(\mathrm{NH}_{4}\right)_{2} \mathrm{SO}_{4}$ & 17.5 & 202 & 1752 & 8.7 & 24 & 0.12 & 73.0 \\
\hline $60-100 \%\left(\mathrm{NH}_{2}, \mathrm{SO}_{4}\right.$ & 17.5 & 137 & 426 & 3.1 & $6 \cdot 3$ & 0.05 & 67.6 \\
\hline $40-60 \%\left(\mathrm{NH}_{4}\right)_{2} \mathrm{SO}_{4}$ & 4 & 80 & 1315 & $16 \cdot 4$ & 18 & 0.26 & $73 \cdot 1$ \\
\hline $\begin{array}{l}\text { Sephacryl S-200 } \\
\text { (see Text-fig. 3a) }\end{array}$ & 26 & 67 & 925 & $13 \cdot 8$ & 17 & 0.25 & $54 \cdot 4$ \\
\hline $\begin{array}{l}\text { DEAE-cellulose } \\
\text { (see Text-fig. 3b) }\end{array}$ & $26 \cdot 5$ & 19 & 858 & $45 \cdot 2$ & 14 & 0.77 & $61 \cdot 3$ \\
\hline
\end{tabular}




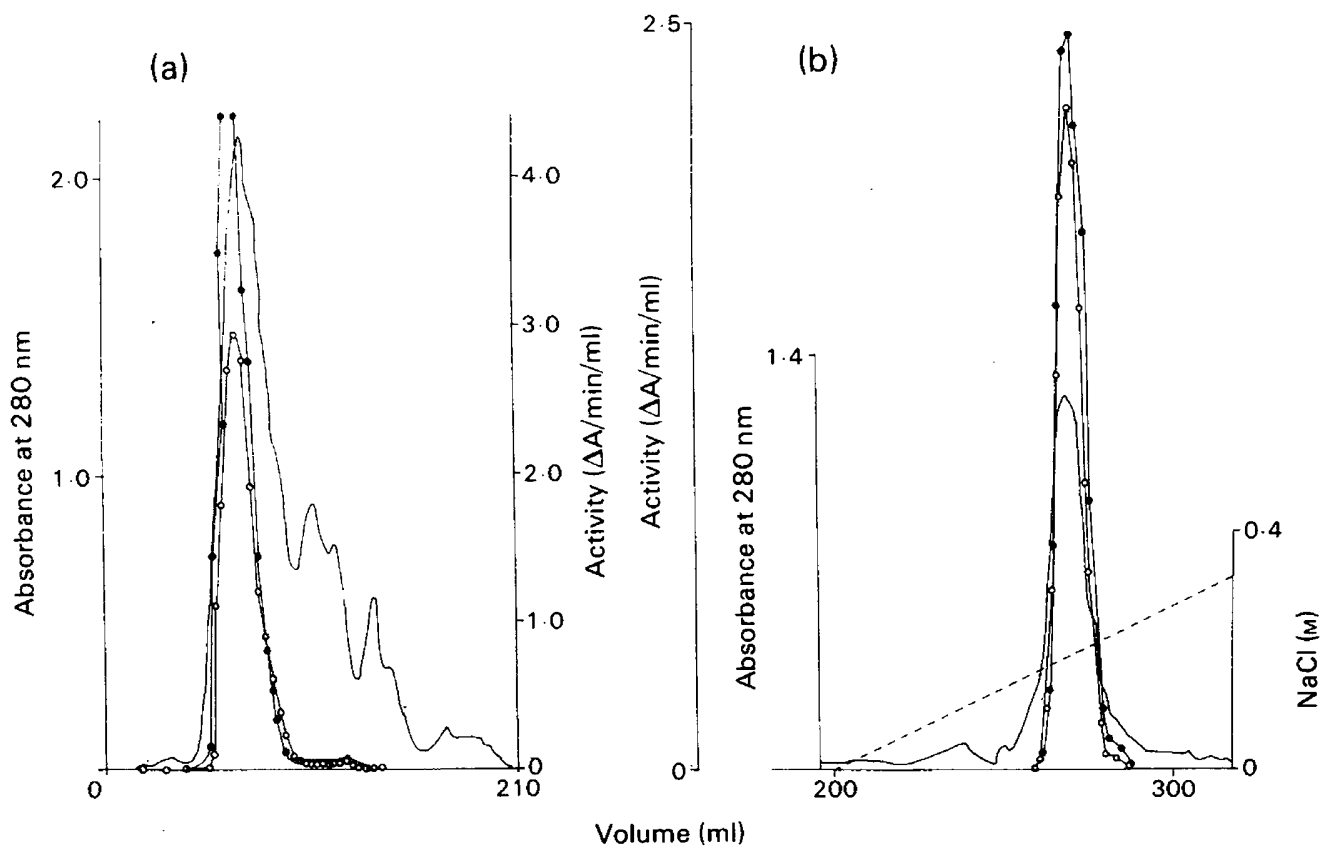

Text-fig. 3. Demonstration of the similarities of acid $(O)$ and alkaline $(O)$ phosphatase activities during purification by (a) chromatography of redissolved $\left(\mathrm{NH}_{4}\right)_{2} \mathrm{SO}_{4}$ precipitate on SephadexSephacryl S-200 and (b) elution from DEAE-cellulose using a salt gradient (---). The solid line represents protein elution.

It was the absence of an alkaline maximum in the $\mathrm{pH}$ profile that led us to suspect that the observed activity at high $\mathrm{pH}$ values could be due to acid phosphatase which is known to be present in large quantity in human semen. All the evidence we have obtained supports this hypothesis. Alternatively if the activity in the alkaline region is due to a combination of residual acid phosphatase and a discrete alkaline phosphatase, then it might be possible to obtain a smooth activity against $\mathrm{pH}$ curve. Equally, the finding that the ratio of activities is not significantly different in 8 split-ejaculate samples does not discount the possibility of there being two enzymes. However, a finding of a significantly differing ratio would have been contrary to the idea that the activity is due to a single enzymic species.

If there are two different phosphatases in human seminal plasma, then they would be expected to respond differently to incubation at elevated temperatures. However, as Text-fig. 2 shows, the acid and alkaline activities behaved very similarly under these conditions. It is also improbable that two distinct proteins would co-purify, maintaining the same ratio of activities, through a purification procedure involving salt precipitation, gel filtration and ion-exchange chromatography.

In view of the results reported here and the absence of any convincing evidence to the contrary, we conclude that the acid phosphatase of human semen probably accounts for all the phosphatase activity observed under alkaline conditions.

\section{References}

Bell, D.J. \& Lake, P.E. (1962) A comparison of phosphomonoesterase activities in the seminal plasmas of the domestic cock, turkey tom, boar, bull, buck rabbit and man. J. Reprod. Fert. 3, 363-368.
Bostrom, K. (1971) Metal (sulphide silver method) and enzyme cytochemical pattern of human seminal spermatozoa. Acta path. microbiol. scand. 79, 345353. 
Bouchilloux, S. \& Menager, J. (1952) Sur le systeme phosphatasique du sperme de belier et de taureau. C.r. Séanc. Soc. Biol. 146, 223-224.

Davies, D.R. (1934) The phosphatase activity of spleen extract. Biochem. J. 28, 529.

Dondero, F., Pozza, D., Mazzulli, F. \& Isidori, A. (1976) Response of adnexal glands to testosterone stimulation in the normal adult male. Fert. Steril. 27, 806-811.

Fernley, H.N. (1971) Mammalian alkaline phosphatases. In The Enzymes, 3rd edn., Vol. IV, pp. 417-447. Ed. P. D. Boyer. Academic Press, New York.

Gutman, A.B. \& Gutman, E.B. (1941) Quantitative relations of a prostatic component (acid phosphatase) of human seminal fluid. Endocrinology, 28, 115-118.

Hollander, V.P. (1971) Acid phosphatases. In The Enzymes, 3rd edn, Vol. IV, pp. 449-498. Ed. P. D. Boyer. Academic Press, New York.

Kipping, D. (1971) Phosphatases in human semen. Clin. chim. Acta 33, 409-413.
Kock, U.J., Lorenz, F., Danehl, K., Ericsson, R., Hason, S.H., Keyserlingt, D.V., Leubke, K., Mehring, M., Rommler, A., Schwartz, U. \& Hammerstein, J. (1976) Continuous oral low-dose Cyproterone acetate for fertility regulation in the male? A trend analysis in 15 volunteers. Contraception 14, 117-135.

Kutscher, W. \& Wolbergs, H. (1935) Prostatic phosphatase. Z. Physiol. Chem. 236, 237-240.

Moon, K.H. \& Bunge, R.G. (1968) Observations on the biochemistry of semen. II. Alkaline phosphatase. Fert. Steril. 19, 766-770.

Murdoch, R.N. \& White, R.G. (1968) The distribution and source of enzymes in mammalian semen. Aust.J. biol. Sci. 21, 483-490.

Warburg, O., \& Christian, W. (1941). Isolierung und Kristallisation des Gärungsferments enolase. Biochem. Z. 310, 384-421.

Wislocki, G.B. (1950) Cytochemical reactions of human spermatozoa and seminal plasma. Anat. Rec. 108, 645-656.

Received 9 November 1978 